\title{
Significant impact of the East Asia monsoon on ozone seasonal behavior in the boundary layer of Eastern China and the west Pacific region
}

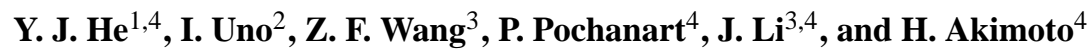 \\ ${ }^{1}$ Earth System Science and Technology, Kyushu University, Fukuoka, Japan \\ ${ }^{2}$ Research Institute for Applied Mechanics, Kyushu University, Fukuoka, Japan \\ ${ }^{3}$ LAPC/NZC, Institute of Atmospheric Physics, Chinese Academy of Science, Beijing, China \\ ${ }^{4}$ Atmospheric Composition Research Program, Frontier Research Center for Global Change, Japan Agency for Marine-Earth \\ Science and Technology, 3173-25 Showa-machi, Kanazawa-ku, Yokohama 236-0001, Japan
}

Received: 9 May 2008 - Published in Atmos. Chem. Phys. Discuss.: 5 August 2008

Revised: 27 October 2008 - Accepted: 13 November 2008 - Published: 17 December 2008

\begin{abstract}
The impact of the East Asia monsoon on the seasonal behavior of $\mathrm{O}_{3}$ in the boundary layer of Eastern China and the west Pacific region was analyzed for 2004-2006 by means of full-year nested chemical transport model simulations and continuous observational data obtained from three inland mountain sites in central and eastern China and three oceanic sites in the west Pacific region. The basic common features of $\mathrm{O}_{3}$ seasonal behaviors over all the monitoring sites are the pre- and post-monsoon peaks with a summer trough. Such bimodal seasonal patterns of $\mathrm{O}_{3}$ are predominant over the region with strong summer monsoon penetration, and become weaker or even disappear outside the monsoon region. The seasonal/geographical distribution of the pre-defined monsoon index indicated that the East Asia summer monsoon is responsible for the bimodal seasonal $\mathrm{O}_{3}$ pattern, and also partly account for the differences in the $\mathrm{O}_{3}$ seasonal variations between the inland mountain and oceanic sites. Over the inland mountain sites, the $\mathrm{O}_{3}$ concentration increased gradually from the beginning of the year, reached a maximum in June, decreased rapidly to the summer valley in July or August, and then peaked in September or October, thereafter decreased gradually again. Over the oceanic sites, $\mathrm{O}_{3}$ abundance showed a similar increasing trend beginning in January, but then decreased gradually from the end of March, followed by a wide trough with the minimum in July and August and a small peak in October or November. A sensitivity analysis performed by setting China-emission to zero revealed that the chemically produced $\mathrm{O}_{3}$ from China-emission
\end{abstract}

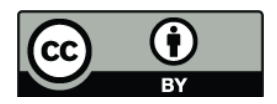

Correspondence to: $\mathrm{Y} . \mathrm{He}$ (yjhe@jamstec.go.jp) contributed substantially to the $\mathrm{O}_{3}$ abundance, particularly the pre- and post-monsoon $\mathrm{O}_{3}$ peaks, over China mainland. We found that China-emission contributed more than $40 \%$ to total boundary layer $\mathrm{O}_{3}$ during summertime $(60-70 \%$ in July) and accounted for about $40 \mathrm{ppb}$ of each peak value over the inland region if without considering the effect of the nonlinear chemical productions. In contrast, over the oceanic region in the high monsoon index zone, the contribution of China-emission to total boundary layer $\mathrm{O}_{3}$ was always less than $20 \%(<10 \mathrm{ppb})$, and less than $10 \%$ in summer.

\section{Introduction}

Ozone is an important trace gas in the troposphere that plays a central role in atmospheric photochemistry and has important effects on regional climates as a greenhouse gas. The high $\mathrm{O}_{3}$ concentrations over East Asia, especially China, can greatly influence the atmospheric environment of surrounding areas, and even Northern Hemisphere, through regional and intercontinental transport (e.g. Akimoto et al., 1996; Zhang et al., 2002, 2003; Liu et al., 2003; Wang, T. J. et al., 2006). The seasonal variations of boundary layer $\mathrm{O}_{3}$ over East Asia have already been widely studied and presented a typical seasonal cycle of spring maximum-summer minimum (e.g. Wild et al., 2001; Pochanart et al., 1999, 2002, 2003; Yamaji et al., 2006). The remarkable spring maximum and summer minimum of boundary layer $\mathrm{O}_{3}$ was also thought to be a common feature at many rural locations, particularly over the humid regions (Higane and Patil, 1996), in the Northern Hemisphere (e.g. Chan et al., 1998; Monks, 2000).

Published by Copernicus Publications on behalf of the European Geosciences Union. 
The spring maximum of surface $\mathrm{O}_{3}$ was once thought to be mainly from stratospheric input since the hemispheric circulation in the stratosphere results in the largest stratospheric $\mathrm{O}_{3}$ concentrations during spring in midlatitudes and the stratospheric intrusion strength is found to be strongest in spring (Levy et al., 1985; Staehelin et al., 1994). Some other studies supposed that the high springtime $\mathrm{O}_{3}$ is contributed substantially by the accumulation of wintertime anthropogenically produced $\mathrm{O}_{3}$ itself due to the relatively long lifetime of $\mathrm{O}_{3}$ in winter (Liu et al., 1987), or the photochemical $\mathrm{O}_{3}$ buildup resulting from the wintertime accumulation of other precursors such as peroxyacetyl nitrate and hydrocarbons together with the enhancement of solar intensity and temperature in spring (Penkett and Brice, 1986; Penkett et al., 1993). Wild and Akimoto (2001) and Pochanart et al. (2002) indicated that intercontinental transport contributes to the spring maximum in East Asia Pacific rim region. Up to present, the $\mathrm{O}_{3}$ spring maximum could be possibly accounted by the combination stratospheric intrusion, intercontinental transport, and regional photochemical production.

The observed summer minimum of surface $\mathrm{O}_{3}$ over East Asia was attributed to the incursion of monsoon which transports oceanic air with less $\mathrm{O}_{3}$ to the region and causes lower $\mathrm{O}_{3}$ concentration (e.g. Wang, H. X. et al., 2006; Pochanart et al., 2001; Zbinden et al., 2006; Chan et al., 1998; Xu et al., 1997; Luo et al., 2000; Yamaji et al., 2006). Similar phenomena have also been observed over other monsoon regions. For example, Pudasainee et al. (2006) found that the observed ground-level $\mathrm{O}_{3}$ during the monsoon was lower than the premonsoon value in the South Asia monsoon region of India. The East Asia monsoon not only affects the seasonal patters of surface $\mathrm{O}_{3}$ over this region, but also results in the lowest summertime transportation of pollutants over all the year from the Asian continent to Japan and other regions because of the weak Asian outflow and northwestward penetration of the maritime air mass (e.g. Zbinden et al., 2006; Yamaji et al., 2006). Furthermore, Tanimoto et al. (2005) indicated that exchanges between continental and maritime air masses driven by the Asian monsoon play a central role in producing the latitudinal differences in $\mathrm{O}_{3}$ seasonality observed at Acid Deposition Monitoring Network in East Asia (EANET) sites.

The peak time of spring maximum in the seasonal pattern of $\mathrm{O}_{3}$ over East Asia was found to shift by several months at different locations (e.g. Waliguan, Hong Kong, Linan, Qingdao, Oki, Hedo), from early spring to early summer (e.g. Chan et al., 1998; Luo et al., 2000; Wang et al., 2001, 2006; Yamaji et al., 2006; Li et al., 2007). Transport from the lower stratosphere and intercontinental transport from outside East Asia may partly account for the difference in peak time (Yamaji et al., 2006). Moreover, besides the common feature of the spring maximum-summer minimum in $\mathrm{O}_{3}$ seasonal pattern, one peak of summer maximum was also observed at some inland locations of East Asia (e.g. Zhu et al., 2004; Ding et al., 2008). Photochemical activities resulting from the intense solar radiation and the high regional-scale emission of the $\mathrm{O}_{3}$ precursors, as well as the long-range transportation from the polluted regions, were proved to be responsible for the $\mathrm{O}_{3}$ summer maximum (Pochanart et al., 1999; Zhu et al., 2004).

Although a great deal of studies have already given a comprehensive discussion on the seasonal variations of boundary layer $\mathrm{O}_{3}$, as well as the possible reasons for the peak values, over East Asia, a detailed analysis of the relationship between East Asia monsoon variability and the $\mathrm{O}_{3}$ seasonal cycle, with the consideration of geographic dependence, is not presented yet. This study focused mainly on the influence of the summer monsoon on the seasonal cycle and geographic distribution of boundary layer $\mathrm{O}_{3}$ over East Asia, by the application of a normalized seasonality monsoon index, based on three years' observational data from three inland mountain sites in central and eastern China and three oceanic monitoring stations in the west Pacific region. Three fullyear nested chemical transport model simulations are also presented. This study is the first to report a detailed comparison of $\mathrm{O}_{3}$ seasonal patterns between inland the mountain sites in central and eastern China and the oceanic sites near Taiwan and southern Japan, on the view of the influence of the East Asia monsoon and the continental anthropogenic emissions.

The structure of this paper is as follows. In Sect. 2, information about the observational data and the regional chemical transport model is briefly presented; the monsoon index (MI) is also defined. Section 3.1 analyzes in detail the seasonal $\mathrm{O}_{3}$ patterns at the monitoring sites. Section 3.2 shows the geographical distributions of $\mathrm{O}_{3}$ and $\mathrm{MI}$, and defines a high-MI zone according to the MI spatial distribution. The impact of the East Asia monsoon on the seasonal behavior of $\mathrm{O}_{3}$ in the high-MI zone is discussed in Sect. 3.3. A sensitivity experiment is applied in Sect. 3.4 that clarifies the contributions of China-emission to regional $\mathrm{O}_{3}$ production. Finally, the main conclusions of this study are given in Sect. 4.

\section{Data and methods}

Two series of observational data were used in this study: one from three inland high mountain monitoring sites, and the other from three remote oceanic stations. The inland monitoring sites are located on the tops of Mt. Hua $\left(110.09^{\circ} \mathrm{E}, 34.49^{\circ} \mathrm{N}, 2064 \mathrm{~m}\right.$ a.s.l.), Mt. Tai $\left(117.10^{\circ} \mathrm{E}, 36.25^{\circ} \mathrm{N}, 1533 \mathrm{~m}\right.$ a.s.l.), and Mt. Huang $\left(118.15^{\circ} \mathrm{E}, 30.14^{\circ} \mathrm{N}, 1836 \mathrm{~m}\right.$ a.s.l.). These mountains are high enough to deviate from the influence of local emissions and can represent the regional background of central and eastern China. More detailed descriptions of these mountain monitoring sites are given by Wang et al. (2006) and Li et al. (2007). The three oceanic monitoring stations are Wanli $\left(121.68^{\circ} \mathrm{E}, 25.18^{\circ} \mathrm{N}\right)$, which is at the northern tip of Taiwan, Hedo/Okinawa $\left(128.26^{\circ} \mathrm{E}, 26.85^{\circ} \mathrm{N}\right)$ and Ogasawara 
$\left(142.2^{\circ} \mathrm{E}, 27.0^{\circ} \mathrm{N}\right)$ in Japan. The Hedo and Ogasawara sites were selected from EANET stations (http://www.eanet.cc/ index.html) and are on isolated islands in the southern ocean region of Japan. These two oceanic sites are only slightly affected by local and domestic emissions for locating far away from mega-city source regions. In addition, observational data from Mondy $\left(101.0^{\circ} \mathrm{E}, 51.67^{\circ} \mathrm{N}\right)$, one EANET station, was also used as a typical Northern Hemisphere continental background site. The locations of all of the monitoring sites are shown in Fig. 1. According to the potential impact of continental emission and the East Asia monsoon, all the monitoring sites are classified into five categories: clean monsoon oceanic site (CMO), polluted monsoon oceanic site (PMO), polluted monsoon inland site (PMI), polluted inland site (PI), and non-monsoon inland site (NMI). Among the monitoring sites, Hedo and Ogasawara are treated as CMO for it's far away from the continental region and has the least impact of continental emissions, and is strongly affected by the monsoon; Wanli is classified into PMO, which is located in the strong monsoon region and can be potentially affected by local anthropogenic emissions; Mt. Tai and Mt. Huang are located in the polluted continental region and are impacted strongly by the monsoon, classified into PMI; Mt. Hua is treated as PI, as it's also strongly affected by regional anthropogenic emissions and have relatively slight influence of the monsoon; Mondy is located at high latitude region and far away from monsoon influence, and treated as NMI. The $\mathrm{O}_{3}$ seasonal patterns at each category site are slightly different to that at other site in details. Observational data (daily mean values) of three years (2004-2006) from all these sites were systematically analyzed. The missing data due to the equipment malfunction or electronic power-shortage, as well as the data of the intercalary day, are excluded from the analysis.

A three-dimensional nested regional-scale chemical transport model, Models-3/Community Multiscale Air Quality (CMAQ, ver 4.4, Byun and Ching, 1999) modeling system released by the US Environmental Protection Agency, was used. Briefly, the model is driven by meteorological fields, which are generated by the Regional Atmospheric Modeling System (RAMS) with initial and boundary conditions defined by US National Centers for Environmental Prediction (NCEP) reanalysis data. The resolution of the model are $80 \mathrm{~km}$ and $20 \mathrm{~km}$ for the mother domain and the nested domain respectively in horizontal direction, and 19 layers in the sigama-z coordination system up to $23 \mathrm{~km}$. The Regional Emission Inventory in Asia (REAS; Ohara et al., 2007), which is based on several energy statistics, emission factors, and other socioeconomic information and covers the years 1980-2003, was used to drive the model. In this study, three full-year nested simulations were performed for 2004-2006, with the fixed emission inventory of 2003 (shown in Fig. 1) used for the control experiment (referred to as CNTL). The initial fields and monthly averaged lateral boundary conditions for most chemical tracers were obtained from a global

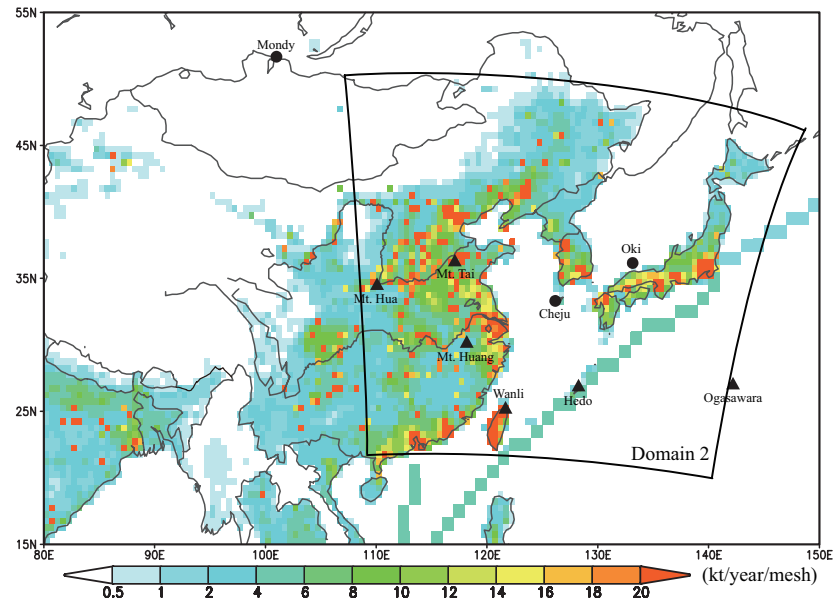

Fig. 1. Geographical distribution of REAS anthropogenic $\mathrm{NO}_{\mathrm{x}}$ emission intensity $\left(\mathrm{kt} /\right.$ year per mesh) $\left(0.5^{\circ} \times 0.5^{\circ}\right)$ in 2003 , used in the model simulations. The region of the nested CMAQ domain is enclosed by the black square. The locations of monitoring sites are indicated by solid triangles and circles.

chemical transport model (CHASER; Sudo et al., 2002). These monthly lateral boundary conditions were used for all simulations with the assumption of no interannual variation. Additionally, a sensitivity experiment in which Chinaemission (excluding Taiwan) was set to zero (referred to as COFF) was also conducted to examine the contribution of China-emission to $\mathrm{O}_{3}$ abundance over East Asia.

The monsoon is an important component of the global circulation system. In monsoon regions, the local weather and climate, especially the precipitation, are strongly influenced by the monsoon circulation. Therefore, a pre-defined monsoon index (MI) plays an important role to quantitatively examine the strength and variations of monsoon circulation in certain monsoon regions. As the geographical distributions and seasonal patterns of $\mathrm{O}_{3}$ in the boundary layer over East Asia is strongly affected by summer monsoon, we supposed that MI could be capable for elucidating the primary features of $\mathrm{O}_{3}$ variations and distributions over this region, particularly in summer. For the East Asia monsoon region, many studies have already defined various indices based on considerations of thermodynamics and dynamics from different aspects, such as relative humidity, pressure, difference of ocean-land temperature, wind field, and so on. Each MI pays attention on some specific physical processes and represents its own meanings different to others. In this study, we used a dynamical normalized seasonality MI, which was developed by Li and Zeng $(2002,2003)$ on the basis of grid-bygrid and season-by-season calculations of the climatological wind field, to define the monsoon region and also to investigate the influence of the monsoon on $\mathrm{O}_{3}$ seasonal behavior in the boundary layer of East Asia. 


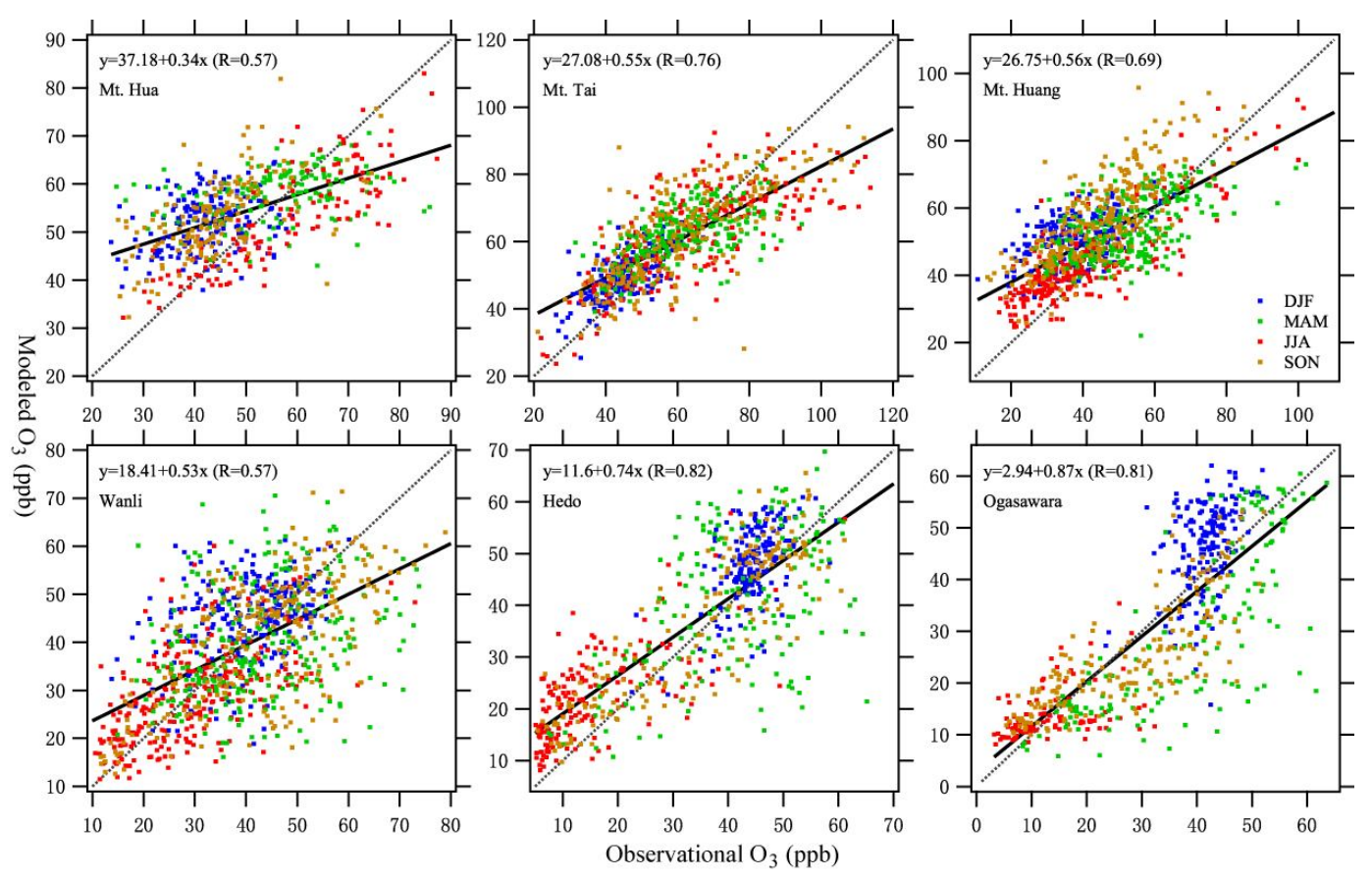

Fig. 2. Comparison of daily mean $\mathrm{O}_{3}$ concentration between observations and model simulations during 2004-2006. The blue, green, red, and orange dots represent the correlations between observational and modeled daily mean $\mathrm{O}_{3}$ in winter (DJF), spring (MAM), summer (JJA), and autumn (SON), respectively. The black solid line is the linear regression line of the daily average $\mathrm{O}_{3}$ value between the observations and simulations for the period of 2004-2006.

The dynamical normalized seasonality MI is defined as follows:

$\delta=\frac{\left\|\overline{V_{1}}-V_{i}\right\|}{\|\bar{V}\|}-2$

where $\overline{V_{1}}$ and $V_{i}$ are the January climatological and monthly wind vectors, respectively, at a given point, and $\bar{V}$ is the mean of the January and July climatological wind vectors at the same point. The norm $\|A\|$ is defined as $\|A\|=\left(\iint_{S}|A|^{2} d S\right)^{1 / 2}$, where $S$ denotes the domain of integration (in calculations at a point $(i, j)$,

$$
\begin{gathered}
\left\|A_{i, j}\right\| \approx \sqrt{\alpha}\left(\left(\left|A_{i-1, j}^{2}\right|+\left|A_{i, j}^{2}\right|+\left|A_{i+1, j}^{2}\right|\right) \cos \varphi_{j}\right. \\
\left.+\left|A_{i, j-1}^{2}\right| \cos \varphi_{j-1}+\left|A_{i, j+1}^{2}\right| \cos \varphi_{j+1}\right)^{1 / 2}
\end{gathered}
$$

where $\alpha$ is the mean radius of the earth and $\varphi_{j}$ is the latitude at point $(i, j))$. More detailed descriptions and applications of the dynamical normalized seasonality MI are presented by $\mathrm{Li}$ and Zeng $(2002,2003)$. As the interannual variability of monsoon is not the main topic of this study, for simplicity, only three years' mean wind vectors during 2004-2006 are applied in the calculation instead of the climatological data. This processing method was confirmed to have negligible influence on the geographical dependence and seasonal variation of the MI. Because the computation of the dynamical normalized seasonality MI depends completely on wind vectors, the value of MI principally represents the intensity of wind direction alternation from winter to summer. For East Asia, as the northwest wind is predominant in winter, then the higher MI primarily represents the stronger southeast wind in summer. Compared with the orthodox climatological monsoon concept, the application of the MI can reveal the primary features of the special natural phenomenon both its seasonal variation and geographical distribution.

\section{Results and discussion}

\subsection{Validation of simulated $\mathrm{O}_{3}$ by comparison with observations}

In order to validate the model performance, the simulation results were compared with observations based on daily averaged $\mathrm{O}_{3}$ concentrations, as illustrated by the scatter plot shown in Fig. 2. In general, model simulations well reproduced the daily $\mathrm{O}_{3}$ concentrations at all the monitoring sites in each season. During 2004-2006, the correlation coefficients of the daily mean $\mathrm{O}_{3}$ between the simulations and observations ranged from $\sim 0.57$ to $\sim 0.76$ for the inland mountain sites, and from $\sim 0.57$ to $\sim 0.82$ for the oceanic stations. The three year correlation coefficients for the daily averaged 
$\mathrm{O}_{3}$ value over the oceanic monitoring stations of Hedo and Ogasawara are quite excellent, which was similar to the conclusions conducted by comparing the CMAQ simulations with the daily $\mathrm{O}_{3}$ concentrations at Japanese monitoring sites of EANET during 2002 (Yamaji et al., 2006). In contrast, the three year correlation coefficients are a bit lower at Wanli and the three inland mountain sites. As for Wanli, the potential effect of local emissions (as shown in Fig. 1) should be mainly responsible for the difference between the modeled and observed daily averaged $\mathrm{O}_{3}$ concentrations. With regard to the three inland mountain sites, the relatively inferior correlations between the modeled and observed daily mean $\mathrm{O}_{3}$ abundance are primarily attributed to the high altitude levels. At the top of the mountains, particularly Mt. Hua, the altitude is near or even slightly beyond the boundary layer height. The model simulations are usually hard to capture the sophisticated physical processes at the boundary layer height level exactly in details due to the coarse vertical resolutions (which is set about $500 \mathrm{~m}$ thickness near the top of boundary layer height in our model simulations).

As shown in the figures, model simulations slightly overestimated the lower $\mathrm{O}_{3}$ concentrations, and somewhat underestimated the higher $\mathrm{O}_{3}$ values; that reflects that the model simulations may slightly underestimate the $\mathrm{O}_{3}$ seasonal variations, as well as the amplitude of the short-term variability. Over the inland mountain sites, model simulations overestimated the daily $\mathrm{O}_{3}$ magnitude in most days of winter and autumn, and underestimated the $\mathrm{O}_{3}$ values in most of the higher $\mathrm{O}_{3}$ days of summer and spring. As for the oceanic sites, model simulations overestimated the daily $\mathrm{O}_{3}$ concentrations in most days of winter and summer, and underestimated the daily mean $\mathrm{O}_{3}$ in most days of spring and autumn. The different correlations of the simulations and observations between the inland mountain and oceanic sites demonstrated the different $\mathrm{O}_{3}$ seasonal patterns, which will be detailed discussed in following sections. There are several factors should be responsible for the systematic difference between the model simulations and the observations. Firstly, the application of the emission inventory of 2003 for the simulations of 20042006, as well as the potential underestimation in emission inventory, will lead to the underestimation for the higher $\mathrm{O}_{3}$ concentrations. Secondly, the neglect of the emission seasonality in model simulations may slightly underestimate the $\mathrm{O}_{3}$ seasonal variations. In addition, the lateral and boundary conditions could result in the small difference between model simulations and observations. The input of the stratospheric $\mathrm{O}_{3}$ and the vertical transport may also lead to the overestimation or underestimation for model simulations, particularly at the inland high mountain sites. Anyhow, despite of the small difference, the model simulations well reproduced the daily $\mathrm{O}_{3}$ concentration at all the monitoring sites during the three years, and were qualified for the applications to investigate the $\mathrm{O}_{3}$ spatial and temporal distributions over eastern China and west Pacific region.

\subsection{Bimodal seasonal patterns of $\mathrm{O}_{3}$}

Figure $3 \mathrm{a}$ and $\mathrm{b}$ show observed and modeled seasonal variations of $\mathrm{O}_{3}$ at the different monitoring sites. All values were calculated based on the daily mean from the three year (2004-2006) average, and then smoothed by 15-day moving average. The most remarkable feature of both the observed and modeled seasonal cycles of $\mathrm{O}_{3}$ concentration is the bimodal pattern with a deep summertime trough. However, the depth and width of the summer trough in the $\mathrm{O}_{3}$ seasonal pattern was different between the inland mountain sites (Mt. Hua, Mt. Tai, and Mt. Huang) and the oceanic monitoring stations (Wanli, Hedo, and Ogasawara).

Over the inland mountain sites, the observed $\mathrm{O}_{3}$ concentration increased gradually from $\sim 40 \mathrm{ppb}$ in January to peak values of about 74, 87, and $63 \mathrm{ppb}$ at Mt. Hua, Mt. Tai, and Mt. Huang, respectively, in June. Then, the observed $\mathrm{O}_{3}$ abundance decreased rapidly and reached the valley value of about 39, 46, and $32 \mathrm{ppb}$ at Mt. Hua, Mt. Tai, and Mt. Huang, respectively, in late July or August. Subsequently, the observed $\mathrm{O}_{3}$ abundance recovered, reaching a second peak of $\sim 62 \mathrm{ppb}$ at Mt. Hua in late August to early September, and of $\sim 73$ and $\sim 55 \mathrm{ppb}$ at Mt. Tai and Mt. Huang, respectively, in October. Finally, the $\mathrm{O}_{3}$ concentration gradually decreased to the end of year. In contrast, over the oceanic sites (Fig. 3a), the observed $\mathrm{O}_{3}$ variation trend exhibited a wide trough from the end of March to October or November, whereas during January-March/October-December, the increasing/deceasing trend was similar to or nearly coincided with the $\mathrm{O}_{3}$ variation trend over the inland mountain sites. The two endpoints of the wide $\mathrm{O}_{3}$ trough can be understood as the splitting and merging points of $\mathrm{O}_{3}$ variation trend between the inland mountain sites and oceanic sites, and they are treated as peaks of $\mathrm{O}_{3}$ seasonal variations for the oceanic sites.

As shown in Fig. 3b, modeled $\mathrm{O}_{3}$ at the inland sites of Mt. Hua, Mt. Tai and Mt. Huang showed two peaks in June and September/October and a summer trough in July/August. Modeled $\mathrm{O}_{3}$ at the oceanic sites of Wanli, Hedo and Ogasawara presented a wide trough from April to October, with the minimum in July or early August. Model simulations also well captured the different $\mathrm{O}_{3}$ seasonal trends between the inland and oceanic sites during the period of April-October, as shown by the observational data. It should be noticed that model simulations somewhat underestimated the absolute magnitudes, especially the first peak values at the inland mountain sites, and overestimated the summer valley values, as indicated in Table 1. One possible reason for the underestimation is the use of the emission inventory for 2003 (chosen because it is the most recent available year of the REAS emission inventory) in the calculation of 2004-2006 model simulations, as reported by He et al. (2007) and Uno et al. (2007). Furthermore, the absence of crop burning and soil $\mathrm{NO}_{\mathrm{x}}$ emissions in the model simulation may also aggravate the underestimation of peak values at the polluted inland 

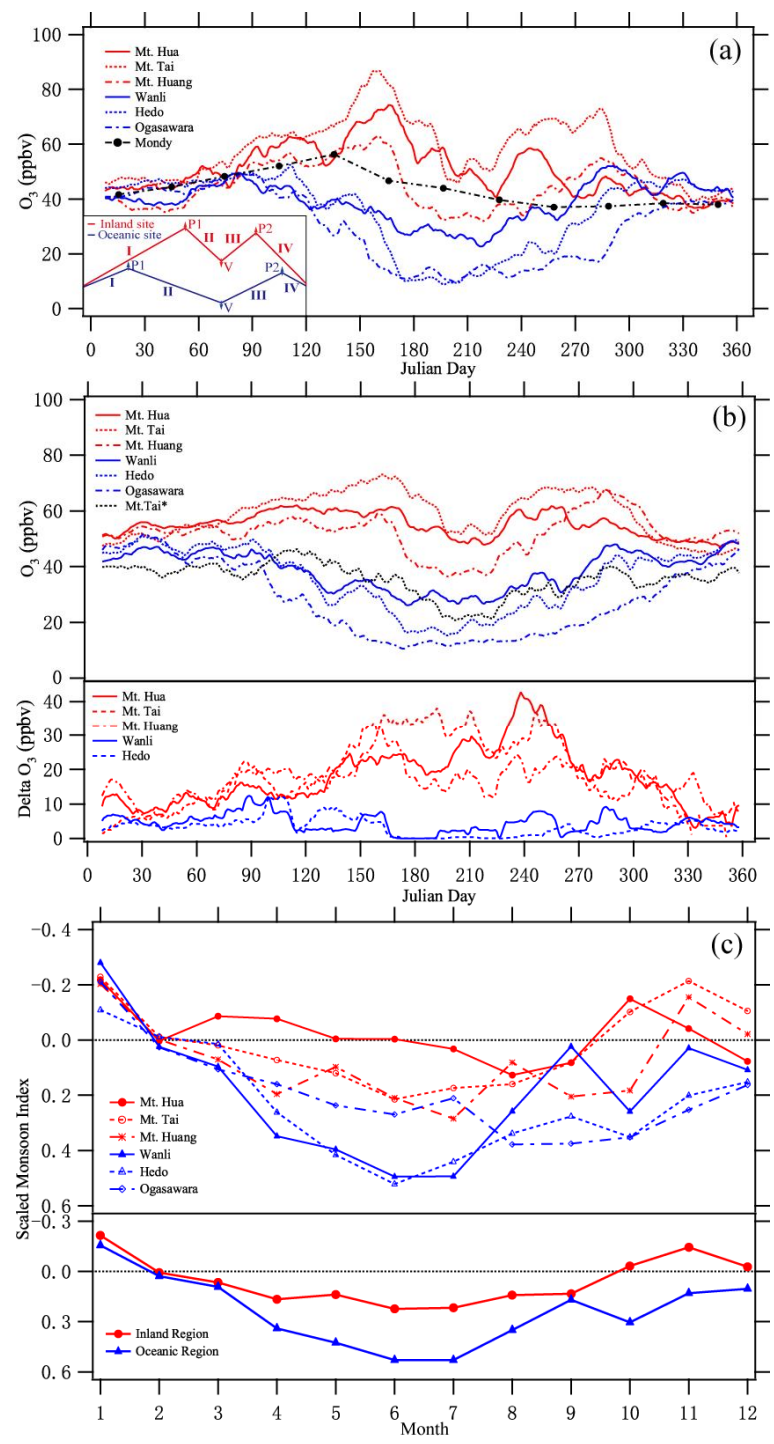

Fig. 3. Seasonal variations of observed $\mathrm{O}_{3}(\mathbf{a})$, modeled $\mathrm{O}_{3}(\mathbf{b})$, and the scaled monsoon index (c) over inland mountain sites (red lines) and oceanic stations (blue lines) in East Asia during 20042006. Monthly averaged values at Mondy $\left(101^{\circ} \mathrm{E}, 51.67^{\circ} \mathrm{N}\right)$ are also presented (black lines). All of the daily mean data were calculated based on the mean of three years' data and then smoothed by using a 15-day running average. In (a), the inset in the lower left corner shows the typical $\mathrm{O}_{3}$ seasonal patterns for inland sites and oceanic sites; P1 and P2 are the first and second peaks, respectively, and V represents the summer minimum; I, II, III, and IV represent the four phases, which are bounded by the two peaks and the summer minimum, of the full-year $\mathrm{O}_{3}$ variations. In (b), Mt. Tai* shows the $\mathrm{O}_{3}$ values with China-emission setting to zero (COFF sensitivity experiment); and delta $\mathrm{O}_{3}$ is the modeled $\mathrm{O}_{3}$ difference between the CNTL and COFF experiments. In (c), the land region is the area within $110-120^{\circ} \mathrm{E}, 30-38^{\circ} \mathrm{N}$, including the inland mountain sites of Mt. Hua, Mt. Tai, and Mt. Huang; the oceanic region is the area within $121-129^{\circ} \mathrm{E}, 24-27^{\circ} \mathrm{N}$, including the oceanic sites of Wanli and Hedo; and Mt. Hua, Mt. Tai, Mt. Huang, Wanli, Hedo, and Ogasawara represent a region of $3^{\circ} \times 3^{\circ}$ centered at each monitoring sites. sites. While for the overestimations of summer minimum, the possible reason may come from the lateral boundary conditions, but the detailed reason is still unknown. Although the model simulations underestimated the amplitude of $\mathrm{O}_{3}$ seasonal variations, the typical seasonal pattern of double peaks and summer minimum is still consistent with observations.

To facilitate explicit description and comparison, the fullyear $\mathrm{O}_{3}$ time series was divided into four phases by the two peaks and the summer valley (the lowest point). The peak and valley point are determined from the maxima and minima values around the notable turning point during a considerable period of about 3 months (a proper period which is long enough to neglect the small fluctuations). The period from the beginning of the year to the first peak was defined as the first phase; the second phase was defined as that occurring from the first peak to the summer valley; from there to the second peak was treated as the third phase; and the remainder of the year was defined as the fourth phase (Fig. 3a, inset). The relevant parameters of the observations and model simulations are listed in Table 1 . The different seasonal behavior of $\mathrm{O}_{3}$ between the inland mountain sites and the oceanic sites is evident from the values of the relevant parameters. In general, $\mathrm{O}_{3}$ concentrations at inland sites are much higher than that at the oceanic sites, both for the peak values and summer minimum, due to the much stronger influence of regional anthropogenic emissions. The summer trough in $\mathrm{O}_{3}$ seasonal cycle at the oceanic sites was much wider than that at the inland sites, and the relative amplitude of $\mathrm{O}_{3}$ variations between the peak (average of the two peaks) and valley value $\left(R_{P V}=\left(\mathrm{O}_{3 \text {.peak }}-\mathrm{O}_{3 \text {. valley }}\right) \times 100 \% / \mathrm{O}_{3 \text {. peak }}\right)$ at the oceanic sites were also higher than that at the inland sites, both for the observational data and model simulations. In addition to the apparent differences in the $\mathrm{O}_{3}$ seasonal patterns between the inland sites and oceanic sites, the detailed $\mathrm{O}_{3}$ features were slightly different among the oceanic sites of CMO and PMO. The first peak at Wanli appeared in late March with the value of $49.5 \mathrm{ppb}$, similar to the peak values at Hedo of $52.5 \mathrm{ppb}$ and Ogasawara of $49.6 \mathrm{ppb}$, and the second peak value at Wanli of $52.1 \mathrm{ppb}$ was slightly higher than $47.2 \mathrm{ppb}$ at Hedo and much higher than $39.5 \mathrm{ppb}$ at Ogasawara, and the second peak time at Wanli was also earlier than that at Hedo and Ogasawara by one or two months. The largest difference in the $\mathrm{O}_{3}$ seasonal pattern between Wanli and Hedo/Ogasawara was the valley minimum, which at Wanli was about $22.7 \mathrm{ppb}$ and occurred in August, whereas it was only 8.7 and $9.5 \mathrm{ppb}$ at Hedo and Ogasawara, respectively, and occurred in July. As a result, the $R_{P V}$ at Wanli of $55.3 \%$ (44.6\%) was much lower than that at Hedo of $82.5 \%(67.5 \%)$ and at Ogasawara of $78.7 \%(78.3 \%)$ for observed (modeled) data. This phenomenon suggests that Wanli is affected by the contaminated air mass, and Taiwan local emissions are much stronger than Hedo and Ogasawara sites, which could be seen from the anthropogenic $\mathrm{NO}_{\mathrm{x}}$ emission distributions shown in Fig. 1. As for the inland sites of PMI and PI, there was also some difference in $\mathrm{O}_{3}$ seasonal 
Table 1. Principal parameters of the typical $\mathrm{O}_{3}$ seasonal patterns for inland and oceanic sites in East Asia during 2004-2006.

\begin{tabular}{|c|c|c|c|c|c|c|c|c|c|c|c|}
\hline \multirow[b]{2}{*}{ Site } & \multicolumn{2}{|c|}{ Peak I } & \multicolumn{2}{|c|}{ Peak II } & \multicolumn{2}{|c|}{ Valley } & \multirow[b]{2}{*}{$\begin{array}{l}\text { Rpv } \\
(\%)\end{array}$} & \multicolumn{4}{|c|}{ Slope (ppb/day) } \\
\hline & Month & $\begin{array}{l}\text { Value } \\
(\mathrm{ppb})\end{array}$ & Month & $\begin{array}{l}\text { Value } \\
(\mathrm{ppb})\end{array}$ & Month & $\begin{array}{l}\text { Value } \\
(\mathrm{ppb})\end{array}$ & & $\begin{array}{l}\text { Phase } \\
\text { I }\end{array}$ & $\begin{array}{l}\text { Phase } \\
\text { II }\end{array}$ & $\begin{array}{c}\text { Phase } \\
\text { III }\end{array}$ & $\begin{array}{l}\text { Phase } \\
\text { IV }\end{array}$ \\
\hline Mt. Hua & Jun & $74.3(61.5)$ & Aug-Sep & $62.1^{*}(61.7)$ & Aug & $38.9(51.5)$ & $43.0^{*}(16.4)$ & $0.18(0.06)$ & $-0.46(-0.24)$ & $1.66^{*}(0.35)$ & $-0.15^{*}(-0.12)$ \\
\hline Mt. Tai & Jun & 86.9 (72.9) & Oct & $72.8(68.4)$ & Jul-Aug & $46.1(51.5)$ & $42.3(27.1)$ & $0.23(0.16)$ & $-0.90(-0.43)$ & $0.28(0.56)$ & $-0.35(-0.30)$ \\
\hline Mt. Huang & Jun & $62.9(59.2)$ & Oct & $54.8(67.7)$ & Jul-Aug & $32.0(36.4)$ & $45.6(42.6)$ & $0.18(0.03)$ & $-0.92(-0.61)$ & $0.31(0.38)$ & $-0.23(-0.23)$ \\
\hline Wanli & Mar & $49.5(47.0)$ & Oct & $52.1(48.0)$ & Aug & $22.7(26.3)$ & $55.3(44.6)$ & $0.13(0.04)$ & $-0.17(-0.17)$ & $0.35(0.15)$ & $-0.09(-0.25)$ \\
\hline Hedo & Apr & $52.5(50.0)$ & Nov & $47.2(44.1)$ & Jul & $8.7(15.3)$ & $82.5(67.5)$ & $0.05(/)$ & $-0.53(-0.31)$ & $0.34(0.26)$ & $-0.12(/)$ \\
\hline Ogasawara & Mar & $49.6(51.6)$ & Dec & $39.5(46.2)$ & Jul & $9.5(10.6)$ & 78.7 (78.3) & $0.10(/)$ & $-0.38(-0.31)$ & $0.23(0.19)$ & $(/)$ \\
\hline
\end{tabular}

All values are based on three-year mean values and a 15-day running average, the observed data is shown in the upper of each cell, and the modeled value is shown in the lower in the bracket of each cell. The definitions of peak and valley, as well as the four phases, are described in Sect. 3.1, and illustrated in Fig. 2a. $R_{P V}=\left(\mathrm{O}_{3}\right.$.peak $\left.-\mathrm{O}_{3 . \text { valley }}\right) \times 100 \% / \mathrm{O}_{3}$.peak is the relative amplitude of $\mathrm{O}_{3}$ variations between the peak (average of the two peaks) and valley value. The slopes were obtained by linear regression of daily data during each phase, and the less reliable calculated data with the confidence interval larger than 0.05 is omitted, replaced by slash.

* These data are considered much less reliable because of many missing values during the period covered by the phase.

behaviors. Model simulations shown that $R_{P V}$ at Mt. Hua $(16.4 \%)$ was much lower than that at Mt. Tai $(27.1 \%)$ and Mt. Huang (42.6\%), the increase/decrease rates during phase II and III at Mt. Hua were also lower than that at Mt. Tai and Mt. Huang. This phenomenon indicates that the influence of East Asia summer monsoon is relatively weak at Mt. Hua, but much stronger at Mt. Tai and Mt. Huang (detailed discussed in Sects. 3.3 and 3.4). Because a number of missing values were involved in the calculation for observational data at Mt. Hua during phase III and IV, the relevant parameters were less reliable and marked by right superscript star in Table 1 .

The $\mathrm{O}_{3}$ seasonal pattern was different at NMI of Mondy, exhibiting only one peak in May. Mondy is a high-latitude site far from the influence of the monsoon (Fig. 4), and the single-peak cycle is the typical $\mathrm{O}_{3}$ seasonal pattern over nonmonsoon regions of the Northern Hemisphere (Zhu et al., 2004; Ding et al., 2008).

3.3 Seasonal cycle and geographical distribution of $\mathrm{O}_{3}$ in relation to the monsoon index

The distinct $\mathrm{O}_{3}$ seasonal patterns at the inland mountain sites and oceanic sites can be partly explained by the differences in the seasonal variations of the MI (Fig. 3c, note that the MI values were converted to a logarithmic scale to show differences more clearly). Over the ocean region, the MI increased rapidly from March and reached a maximum in June and July. In contrast, over the inland sites the MI was much lower than the ocean region during the same period. This difference indicates that the monsoon was much stronger over the ocean than over the land; the south wind, containing the clean maritime air mass, would thus much more intensively affect the oceanic than the inland region. Therefore, beginning in April, $\mathrm{O}_{3}$ began to decrease over the oceanic sites of Wanli, Hedo, and Ogasawara, but continued to increase over the inland sites of Mt. Hua, Mt. Tai, and Mt. Huang until the maximum MI appeared in June. Except the remote clean Ogasawara site, the amplitude of MI variations decreased gradually from the polluted oceanic region to deep inland area, with the maximum at Wanli and Hedo and the minimum at Mt. Hua. These geographical distributions of MI variation were consistent with the different $\mathrm{O}_{3}$ seasonal patterns of wide trough at the oceanic sites and narrow trough at the inland, as well as the $R_{P V}$ values of $67 \%, 45 \%, 43 \%, 27 \%$, and $16 \%$ at Hedo, Wanli, Mt. Huang, Mt. Tai, and Mt. Hua, respectively. The modeled $R_{P V}$ presented a significant correlation with the summer MI values (average of June, July and August):

$$
R_{P V}=0.13+1.04 \times \mathrm{MI}_{\mathrm{JJA}}, \quad(R=0.88, P<0.05) .
$$

Therefore, the application of MI could partly identify the $\mathrm{O}_{3}$ seasonal behavior, particularly the summer trough, over East Asia monsoon region.

The prevailing south/southeast summer monsoon is one of the main factors which should be responsible for the bimodal seasonal $\mathrm{O}_{3}$ patterns over most area of East Asia. However, considering the geographical distribution of the $\mathrm{NO}_{\mathrm{x}}$ emission inventory (Fig. 1), the detailed mechanism of the formation of the $\mathrm{O}_{3}$ summer trough may differ between the inland mountain sites and the oceanic sites. At the inland sites such as Mt. Hua, Mt. Tai, and Mt. Huang, local $\mathrm{O}_{3}$ abundance is mainly produced by the photochemical reaction from its precursors emitted from the regional polluted industrial areas; the summer minimum is primarily due to the dilution of local $\mathrm{O}_{3}$ concentration, as well as its precursors, as a result of the incursion of the clean and moist oceanic air mass carried by East Asia summer monsoon. In contrast, at the oceanic sites of Hedo and Ogasawara, $\mathrm{O}_{3}$ is mainly contributed by outflow from China and the global background concentration (Yamaji et al, 2006); the wide summer $\mathrm{O}_{3}$ trough is primarily due to 

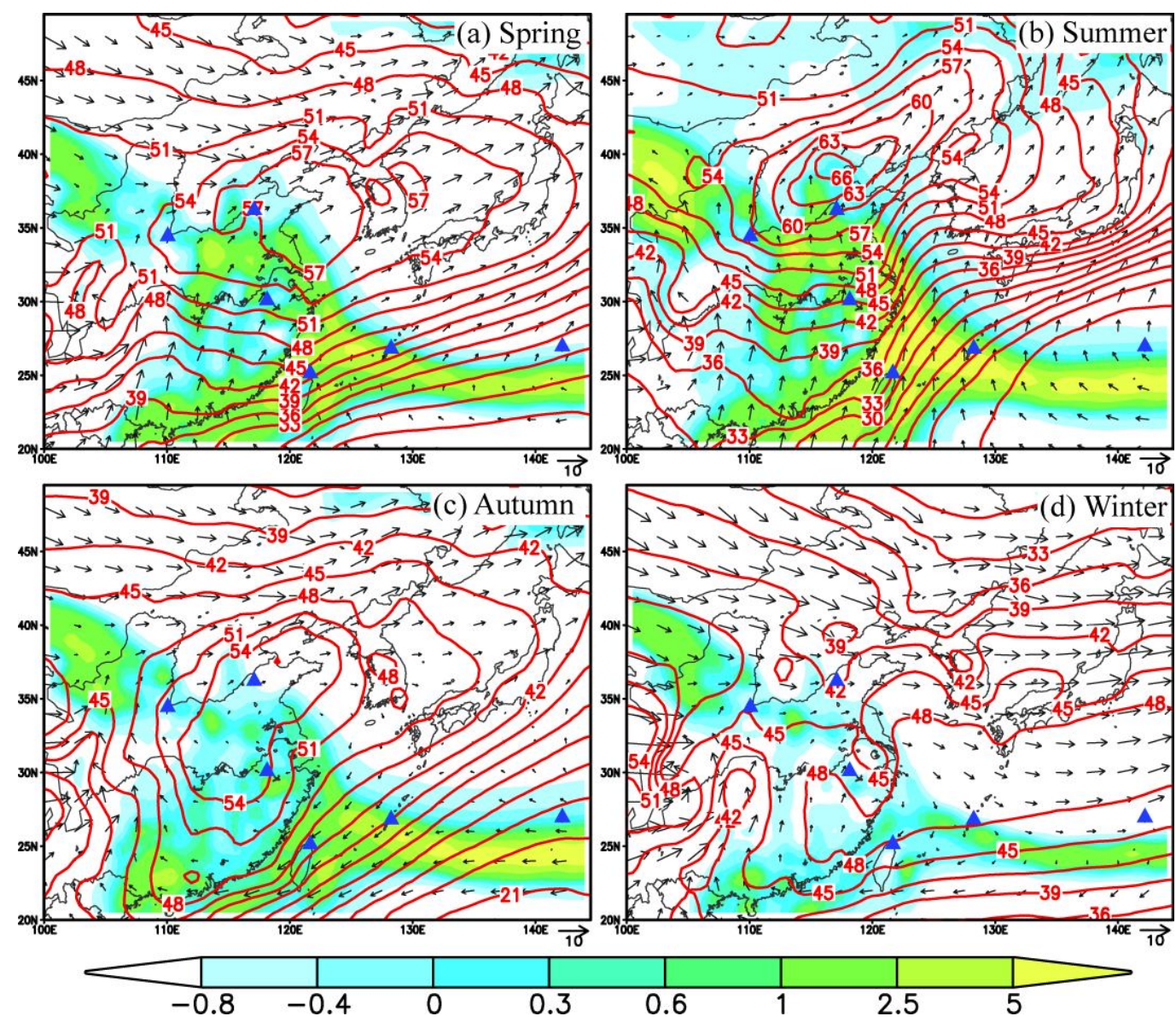

Fig. 4. Modeled three-year (2004-2006) mean seasonal distributions of $\mathrm{O}_{3}$ (ppb), wind vectors, and the monsoon index (MI) in the boundary layer (0-1 km) of East Asia for (a) spring (March, April, and May), (b) summer (June, July, and August), (c) autumn (September, October, and November), and (d) winter (December, January, and February). The $\mathrm{O}_{3}$ concentration is plotted as red contours, and MI is indicated by colored shading. The high-MI zone is shown by the color shade excluding the southeast region of China. From left to right, the blue triangles are the locations of monitoring sites of Mt. Hua, Mt. Tai, Mt. Huang, Wanli, Hedo, and Ogasawara, all of which are within or adjacent to the high-MI zone.

the strong inflow of the clean maritime air mass. The situation of Wanli is similar with that of Hedo and Ogasawara, so the $\mathrm{O}_{3}$ seasonal behavior also presented the "ocean" patterns as Hedo and Ogasawara.

Figure 4 illustrates the modeled seasonal mean geographical distributions of $\mathrm{O}_{3}$, the wind field, and the $\mathrm{MI}$ in the boundary layer $(0-1 \mathrm{~km})$ over East Asia during the four seasons. $\mathrm{O}_{3}$ concentration is plotted as red contour and $\mathrm{MI}$ is indicated by colorized shade. The maximal MI in summer demonstrates the strong south/southeast wind of summer monsoon, and the minimal MI in winter manifests the prevailing northwest wind of winter monsoon. In terms of the spatial distribution of the MI during the four seasons, as well as the geographic locations of the monitoring sites, a high MI zone was selected, as shown in Fig. 4 by the colored shade excluding the southeastern China owing to the absence of observations. Generally, the value of MI is higher within this zone than outside of the zone during all seasons.
It is apparent that the south wind from the west northern Pacific plays an important role in controlling the geographic distribution of $\mathrm{O}_{3}$ in the boundary layer over central and eastern China in spring and summer. In spring, high $\mathrm{O}_{3}$ concentrations $(>57 \mathrm{ppb})$ center are over the Shandong Peninsula and surrounding regions, which located at the northern edge of the monsoon region. South to this area is the main East Asia monsoon region, the large latitudinal gradient of $\mathrm{O}_{3}$ concentration was apparent due to the south/southeast wind originated from the Pacific Ocean. Eastward of the $\mathrm{O}_{3}$ maximum center, the winds change from south to southwest, causing the high $\mathrm{O}_{3}$ region to expand toward the Sea of Japan and the Japanese Islands. This phenomenon is consistent with the observation that the long-range transport of pollutants from North China to Japan occurs strongly in spring (Zhang and Xu et al., 2004). The MI becomes much larger in summer, reflecting the strongest penetration of maritime air masses, steepening the latitudinal $\mathrm{O}_{3}$ gradient over eastern 
China, and also moving the high $\mathrm{O}_{3}$ center, with maximum values $>66 \mathrm{ppb}$, northward to the area of Beijing. Similar to the distribution pattern in spring, the region with high $\mathrm{O}_{3}$ concentrations extends to northeastern China from Beijing because of the southwest winds. The geographical pattern of the steep latitudinal $\mathrm{O}_{3}$ gradient over the monsoon region and the maximum at the northern edge of the monsoon region in spring and summer clearly shows that clean maritime air masses from the Pacific Ocean can carry pollutants northward from the polluted industrial regions of southeast China when passing (Tu et al., 2007), and generating regional $\mathrm{O}_{3}$ pollution over the North China region. With the decreasing monsoon strength in autumn, the maximum center of $\mathrm{O}_{3}$ concentration withdrew from North China and covered most region of eastern China with the value $>54 \mathrm{ppb}$. In winter, the northwest winter monsoon prevails over the region north of $35^{\circ} \mathrm{N}$. The band of relatively high $\mathrm{O}_{3}(>48 \mathrm{ppb})$ that appears over the Pacific Ocean region between $25^{\circ}$ and $35^{\circ} \mathrm{N}$ is from the long-range transport of pollutants from the continental Asia polluted region (Zhang et al., 2002).

\section{4 $\mathrm{O}_{3}$ seasonal cycle in the high MI zone}

Figure $5 \mathrm{a}$ and $\mathrm{b}$ illustrate the variations in daily mean $\mathrm{O}_{3}$ $(\mathrm{ppb})$ in the high MI zone shown in Fig. 4 in the observational data and the model simulations, respectively. The observed contours were constructed by inverse square distance interpolation of the measurements made at the monitoring sites. Both the observed and modeled data are calculated from three-year means and then smoothed by means of a moving average spanning $4.5^{\circ}$ in longitude over 15 days.

The geographical pattern of the observations is quite similar in shape to that of the simulation, except in the region east of $125^{\circ} \mathrm{E}$, where less observational data was available. The significant gradient for the $\mathrm{O}_{3}$ seasonal pattern is apparent along the high MI zone. Over the region between about $110^{\circ} \mathrm{E}$ and $120^{\circ} \mathrm{E}$ (defined as the Polluted Monsoon Inland Region; PMI), in the observed seasonal cycle the first highvalue area appears between March and July, splitting into two sub-peaks of $\sim 65$ and $\sim 75 \mathrm{ppb}$ in April and June, respectively, and a second high-value area appears during later August and October, also splitting into two peaks of $\sim 55$ and $\sim 60 \mathrm{ppb}$ in late August/early September and in October, respectively. From mid-July to mid-August, a summer trough caused by the incursion of the summer monsoon is evident. East of $\sim 123^{\circ} \mathrm{E}$ (defined as the Clean Monsoon Oceanic Region; CMO), the first peak occurs a little earlier and the second is delayed until late October or even November compared with the region west of $120^{\circ} \mathrm{E}$. The corresponding trough period lasted more than two months, compared with about one month over the region west of $120^{\circ} \mathrm{E}$. While between the region of $120^{\circ} \mathrm{E}$ and $123^{\circ} \mathrm{E}$ (defined as the Polluted Monsoon Oceanic region; PMO), $\mathrm{O}_{3}$ seasonal patters present the similar feature as that transiting from PMI to CMO.
The model simulations well reproduce the observed longitudinal seasonal $\mathrm{O}_{3}$ cycles in the high $\mathrm{MI}$ zone and further fetched up the deficiency of the scare monitoring sites. East of $\sim 125^{\circ} \mathrm{E}$, the trough period expands to more than 5 months, with the high values occurring in late January/early February and December, because of the strong winter monsoon that transports pollutants from continental regions to remote clean oceanic regions. West of $\sim 110^{\circ} \mathrm{E}$ (defined as the Polluted Inland Region; PI), the bimodal feature becomes gradually weaker and the two peaks even merge into one summer peak. The south wind is predominant in summer (Fig. 5b), and the region with strong south wind overlaps the summer trough area in both inland and oceanic regions. Wind speed over the oceanic region is much stronger than that over the inland region, and the strong wind region are consistent with the geographical distribution of lower $\mathrm{O}_{3}$ concentrations over the ocean and relatively higher concentrations inland. Simultaneously, RH associated with the summer monsoon is much higher, $\sim 85 \%$, over the ocean, and the area of high $\mathrm{RH}$, reduced by only $\sim 10 \%$, extends inland in July-August. West of $\sim 110^{\circ} \mathrm{E}, \mathrm{RH}$ decreases rapidly, indicating that the humid maritime air mass from the Pacific Ocean brought by the summer monsoon does not reach this region or becomes very weak after its arrival. At the region where the maritime air mass could not reach, the bimodal pattern of the $\mathrm{O}_{3}$ seasonal cycle weakens or even disappears.

3.5 Sensitivity experiment on the influence of regional emissions on $\mathrm{O}_{3}$ bimodal seasonal patterns

As discussed above, the summer monsoon is the predominant factor causing the $\mathrm{O}_{3}$ summer trough. However, it cannot completely account for the two peak values. The $\mathrm{O}_{3}$ concentration in the boundary layer is controlled by many factors, with the primary factors being emission intensity, chemical reactions, meteorological conditions, stratospheric $\mathrm{O}_{3}$ intrusion, and global and intercontinental transport of $\mathrm{O}_{3}$. Yamaji et al. (2006) pointed out that inflow from outside the model domain contributes substantially to the total $\mathrm{O}_{3}$ concentration over East Asia, particularly in early spring and winter. Because the same monthly lateral boundary conditions, taken from the CHASER global CTM, were used for both the CNTL and COFF experiments, the same influence of stratospheric $\mathrm{O}_{3}$ was simulated for CNTL and COFF. Yamaji et al. (2006) also demonstrated that regional chemical production contributed less than $70 \%$ of total $\mathrm{O}_{3}$ in China and $50 \%$ in Japan, according to the observational data collected at Japanese monitoring sites and CMAQ simulations. But their results did not involve the emission contribution to the seasonal variations, and the sharp pre- and post-monsoon $\mathrm{O}_{3}$ peaks in China. To investigate the reasons for the two $\mathrm{O}_{3}$ peaks, a sensitivity experiment in which China-emission (excluding Taiwan) were set to zero (COFF) was conducted for 2005. 

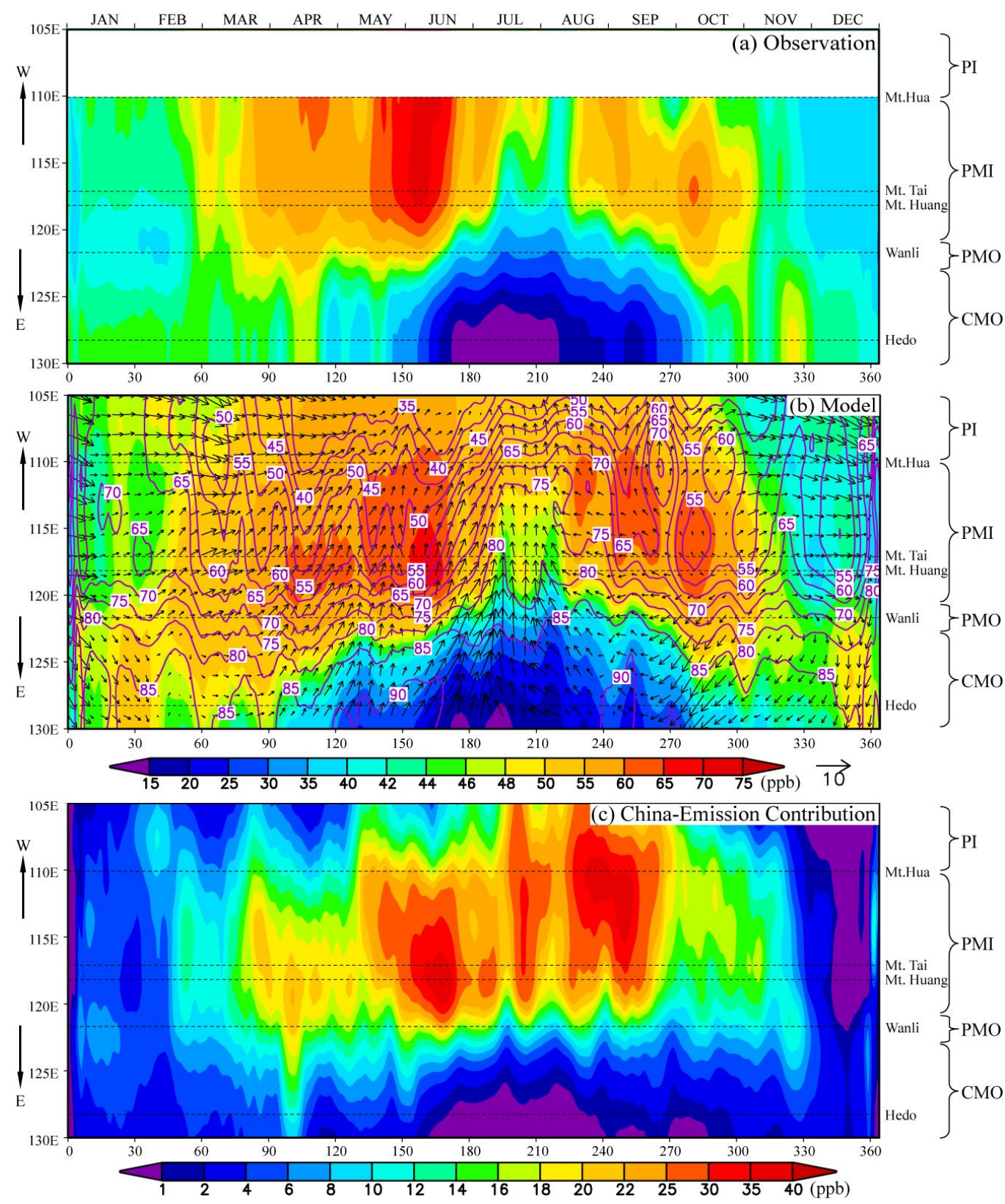

Fig. 5. Variations in daily mean $\mathrm{O}_{3}(\mathrm{ppb})$ for (a) observations and (b) model simulations, and the $\mathrm{O}_{3}$ magnitude of China-emission contribution (c) along the high MI zone (shown in Fig. 3) of East Asia. In (b), the contours show relative humidity and the vectors show the horizontal wind field. The observed results were calculated by inverse square distance interpolation of the measurements at Mt. Hua, Mt. Tai, Mt. Huang, Wanli, Hedo, and Ogasawara, the latitudes of which are marked by dotted lines. The modeled results are based on the mean values in the boundary layer $(0-1 \mathrm{~km})$. Both the observed and modeled data were calculated using three-year means for 2004-2006, and the $\mathrm{O}_{3}$ abundance contributed by China-emission was calculated for 2005 . All values are smoothed by running averages of $4.5^{\circ}$ longitude and 15 days.

The difference in the simulation results between CNTL and COFF in the boundary layer $(<1 \mathrm{~km})$ in the high-MI zone is plotted in Fig. 5c. We also show the $\mathrm{O}_{3}$ difference between CNTL and COFF at the monitoring sites in Fig. $3 \mathrm{~b}$. In this study, we treated this difference as the chemically produced $\mathrm{O}_{3}$ from China-emission (COCE), though it should be potentially overestimated due to the nonlinear chemical productions, particularly over China mainland. The COCE distribution pattern is clearly very similar to that obtained in the CNTL experiment with the concentration more than $20 \mathrm{ppb}$ from the beginning of April to the end of September and about $40 \mathrm{ppb}$ in June and late August/September. As 
for the relative values, COCE contributed $50-70 \%$ of each of the two sharp $\mathrm{O}_{3}$ peaks over the inland region. Additionally, COCE was also responsible for the two sub-peaks in April and October over inland region, with the contributions of about $30 \%$. Notably, COCE was 30-35 ppb during the summer monsoon period over the inland region. This result suggests that the $\mathrm{O}_{3}$ level might be possibly extremely high with the value of about $80 \mathrm{ppb}$ in July if without East Asia summer monsoon; and the summer trough of $\mathrm{O}_{3}$ could probably be even much deeper with the value lower than $20 \mathrm{ppb}$ if no China-emission. For the region west of $110^{\circ} \mathrm{E}$, COCE was predominant during July-September, contributing about $60 \%$ of the total abundance. Over the region between $110^{\circ}$ and $122^{\circ} \mathrm{E}, \mathrm{COCE}$ was higher than $16 \mathrm{ppb}$ from April to October, in summer reaching over $40 \mathrm{ppb}$, with the corresponding contribution to total abundance exceeding $40 \%$. The contribution of China-emissions to total boundary layer $\mathrm{O}_{3}$ is about $20 \%$ in January and February, and about $10 \%$ in December. These results show that $\mathrm{O}_{3}$ pollution over central and eastern China is controlled mainly by regional emissions, particularly in summertime. East of $122^{\circ} \mathrm{E}$, COCE decreased rapidly to less than $10 \mathrm{ppb}$ over Wanli, and even lower than 5 ppb over Hedo. COCE accounts for less than $20 \%$ of total abundance throughout the year, and less than $10 \%$ in summertime, over the region east of $122^{\circ} \mathrm{E}$. Thus, along the high-MI zone, anthropogenic emissions from China strongly affect $\mathrm{O}_{3}$ pollution over the China mainland but have less impact on oceanic areas.

It should be noticed that the above discussions of the sensitivity experiment are based on the assumption that the $\mathrm{O}_{3}$ chemical production is linear under the conditions of Chinaemission on and China-emission off. Due to the nonlinear chemical reactions, however, the real contribution of Chinaemission under current conditions is a little different to that calculated by the sensitivity experiment. As a quantitative estimation, we have already confirmed that the sensitivity experiments with China-emission off may overestimate about $10-20 \%$ for the China-emission contributions over China mainland, and have less effect over the regions outside China, due to the nonlinear chemical productions. Therefore, the effect of the nonlinear chemical productions should be under the acceptable deviation range, the results of the sensitivity experiment are reasonable and reliable.

On the whole, the bimodal $\mathrm{O}_{3}$ seasonal pattern in the boundary layer in East Asia, over both inland regions and the oceanic area, is evidently caused by the incursion of the summer monsoon. Anthropogenic emissions from China contribute substantially to the $\mathrm{O}_{3}$ abundance over the China mainland, particularly in summer, when regional emissions enhance $\mathrm{O}_{3}$ peak values and lessen the depth of the summer trough. Over the oceanic sites, $\mathrm{O}_{3}$ seasonal variation is a function of the northern hemispheric continental $\mathrm{O}_{3}$ background (observed at Mondy; see Fig. 3a), the incursion of clean maritime air masses, and the impact of regional emissions and chemical reactions. The dilution effect by clean maritime air masses lasts from April until October, so the seasonal $\mathrm{O}_{3}$ variation exhibits two peaks (one in March/April and the other in October/November). At Wanli and Hedo, the contribution of China-emission is comparatively small, especially in summertime.

Note that all the analyses above are based on the region along the high MI zone, so the main conclusions might be different from Yamaji et al. (2006) and Tanimoto et al. (2005) because they paid main attention to the impact of Chinaemission on the downwind Japan regions.

\section{Conclusions}

Three full-year simulations for 2004-2006 were conducted with a nested CMAQ model to investigate the seasonal behavior of $\mathrm{O}_{3}$ in the boundary layer in central and eastern China and the west Pacific region. We clearly showed a significant impact of the East Asia monsoon on the distinct bimodal $\mathrm{O}_{3}$ seasonal patterns. Generally, we found that the model simulations well reproduced the bimodal seasonal $\mathrm{O}_{3}$ patterns observed over both inland and oceanic sites. The contributions of China regional emissions to the total surface $\mathrm{O}_{3}$ abundance, especially to the two peak values over the inland region and oceanic area of East Asia, were studied by sensitivity model experiments with China-emission (excluding Taiwan) setting to zero (COFF experiment).

Despite the basic common features of the bimodal seasonal pattern and a summer trough, in detail the structures of the $\mathrm{O}_{3}$ seasonal variations obviously differed between the inland mountain sites and the oceanic stations. At the inland mountain sites, the first peak appeared in June and the second peak in September or October, whereas at the oceanic sites, the first peak occurred two to three months earlier, in March and April, and the second peak was delayed by one or more months, to November and December. The $\mathrm{O}_{3}$ summer valley appeared in late July and August at all monitoring sites. Therefore, the $\mathrm{O}_{3}$ seasonal pattern over the inland region is dominated by two sharp peaks separated by a narrow, deep valley, and that over the oceanic areas is characterized mainly by a wide trough separating two relatively small peaks. Because of the different influence of the anthropogenic emissions and the monsoon, $\mathrm{O}_{3}$ seasonal patterns behavior are slightly different both among the inland mountain sites and oceanic sites. The relative amplitude of $\mathrm{O}_{3}$ abundance between the peak value and summer minimum, is lower at Wanli than at Hedo/Ogasawara due to the contributions of Taiwan local emission, and is also lower at Mt. Hua than at Mt. Tai and Mt. Huang due to the relatively slight influence of East Asia summer monsoon.

The $\mathrm{O}_{3}$ seasonal variations over both inland and oceanic sites correlated well with the variations in the MI. The MI increased more rapidly, beginning in April, over the oceanic region than over the inland region, and reached a maximum in June and July; these changes corresponded to the decreasing 
trend of $\mathrm{O}_{3}$ from April, which reached a minimum in July over the oceanic region. The relative variations of $\mathrm{O}_{3}$ between the peak values and summer valley are significantly correlated with the summer MI values at all the monitoring sites. The influence of the East Asia summer monsoon was predominant over eastern China and the west Pacific region, but tapered off or even disappeared over the region west to $110^{\circ} \mathrm{E}$, where the two peaks in the $\mathrm{O}_{3}$ seasonal cycle attenuated or even merged into one peak, which is the typical $\mathrm{O}_{3}$ seasonal pattern over the non-monsoon regions of the Northern Hemisphere.

China-emission strongly affected the boundary layer $\mathrm{O}_{3}$ abundance over China mainland, particularly to the pre- and post-monsoon $\mathrm{O}_{3}$ peaks. The sensitivity experiment with China-emission setting to zero suggested that the contribution of China-emission is more than $40 \%$ and up to $60-70 \%$ (including about $10-20 \%$ caused by the nonlinear chemical productions) in summertime, with the values of more than $40 \mathrm{ppb}$ to the pre- and post-monsoon $\mathrm{O}_{3}$ peaks over the inland region. Whereas in the oceanic region, China-emission accounted for less than $20 \%$ (less than $10 \mathrm{ppb}$ ) of the total boundary layer $\mathrm{O}_{3}$ abundance throughout the year, and even lower than $10 \%$ in summertime.

Acknowledgements. This work was partly funded by MEXT Research Revolution 2002 Research Project for Sustainable Coexistence of human, nature, and the earth, and subsequently supported by JEM Global Environment Research Fund (B-051). Work Of IAP in this research was funded by the Chinese Academy of Sciences (KZCX2-YW-205), the National Basic Research 973 Grand (2005CB422205) and NSFC grant (40775077). The authors are grateful to T. Ohara and H. Tanimoto and J. Kurokawa of NIES, and to K. Yamaji of FRCGC, for their kind help and discussion of CMAQ simulation and analysis of observational data. The authors also greatly appreciate Liu Y. of IAP for assistance in observation, and Lin Y. C. of RCEC of Taiwan for providing the observational data at Wanli. EANET observational data were provided by the Acid Deposition and Oxidant Research Center (ADORC), Japan.

Edited by: F. J. Dentener

\section{References}

Ahammed, Y. N., Reddy, R. R., Gopal, K. R., Narasimhulu, K. B., Baba, D., Reddy, L. S., and Rao, T. V.: Seasonal variation of the surface ozone and its precursor gases during 2001-2003, measured at Anantapur $\left(14.62^{\circ} \mathrm{N}\right)$, a semi-arid site in India, Atmos. Res., 80(2-3), 151-164, 2006.

Akimoto, H., Mukai, H., Nishikawa, M., Murano, K., Hatakeyama, S., Liu, C. M., Buhr, M., Hsu, K. J., Jaffe, D. A., Zhang, L., Honrath, R., Merrill, J. T., and Newell, R. E.: Long-range transport of ozone in the East Asian Pacific rim region, J. Geophys. Res., 101(D1), 1999-2010, 1996.

Byun, D. W. and Ching, J. K. S.: Science algorithms of the EPA Models-3 community multi-scale air quality (CMAQ) modeling system. National Exposure Research Laboratory, Research Triangle Park, Washington, DC, USA, EPA/600/R99/030, 1999.
Chan, L. Y., Liu, H. Y., Lam, K. S., Wang, T., Oltmans, S. J., and Harris, J. M.: Analysis of the seasonal behavior of tropospheric ozone at Hong Kong, Atmos. Environ., 32(2), 159-168, 1998.

Ding, A. J., Wang, T., Thouret, V., Cammas, J.-P., and Nédélec, P.: Tropospheric ozone climatology over Beijing: analysis of aircraft data from the MOZAIC program, Atmos. Chem. Phys., 8, 1-13, 2008, http://www.atmos-chem-phys.net/8/1/2008/.

Gao, J., Wang, T., Ding, A., and Liu, C.: Observational study of ozone and carbon monoxide at the summit of mount Tai (1534 m a.s.l.) in central-eastern China, Atmos. Environ., 39(26), 4779-4791, 2005.

He, Y., Uno, I., Wang, Z., Ohara, T., Sugirnoto, N., Shimizu, A., Richter, A., and Burrows, J. P.: Variations of the increasing trend of tropospheric $\mathrm{NO}_{2}$ over central east China during the past decade, Atmos. Environ., 41(23), 4865-4876, 2007.

Hingane, L. S. and Patil, S. D.: Total ozone in the most humid monsoon region, Meteorol. Atmos. Phys., 58(1-4), 215-221, 1996.

Li, J., Wang, Z., Akimoto, H., Gao, C., Pochanart, P., and Wang, X.: Modeling study of ozone seasonal cycle in lower troposphere over east Asia, J. Geophys. Res., 112, D22S25, doi:10.1029/2006JD008209, 2007.

Li, J. P. and Zeng, Q. C.: A unified monsoon index, Geophys. Res. Lett., 29(8), 1151-1154, 2002.

Li, J. P. and Zeng, Q. C.: A new monsoon index and the geographical distribution of the global monsoons, Adv. Atmos. Sci., 20(2), 299-302, 2003.

Liu, S. C., Trainer, M., Fehsenfeld, F. C., Parrish, D. D., Willianms, E. J., Fahey, D. W., Hubler, G., and Murphy, P. C.: Ozone production in the rural troposphere and the implications for regional and global ozone distributions, J. Geophys. Res., 92, 4191-4207, 1987.

Liu, H., Jacob, D. J., Bey, I., Yantosca, R. M., Duncan, B. N., and Sachse, G. W.: Transport pathways for Asian pollution outflow over the Pacific: Interannual and seasonal variations, J. Geophys. Res., 108(D20), 8786, doi:10.1029/2002JD003102, 2003.

Levy II, H. J., Mahlman, D., Moxim,W. J., and Liu, S. C.: Tropospheric ozone: The role of transport, J. Geophys. Res., 90, 3735-3772, 1985.

Luo, C., John, J. C., Zhou, X. J., Lam, K. S., Wang, T., and Chameides, W. L.: A nonurban ozone air pollution episode over eastern China: Observations and model simulations, J. Geophys. Res. 105(D2), 1889-1908, 2000.

Monks, P. S.: A review of the observations and origins of the spring ozone maximum, Atmos. Environ., 34(21), 3545-3561, 2000.

Ohara, T., Akimoto, H., Kurokawa, J., Horii, N., Yamaji, K., Yan, X., and Hayasaka, T.: An Asian emission inventory of anthropogenic emission sources for the period 1980-2020, Atmos. Chem. Phys., 7, 4419-4444, 2007, http://www.atmos-chem-phys.net/7/4419/2007/.

Penkett, S. A. and K. A. Brice: The spring maximum in photooxidants in the Northern Hemisphere troposphere, Nature, 319, 655-658, 1986.

Penkett, S. A., Blake, N. J., Lightman, P., March, A. R. W., Anwyl, P., and Butcher, G.: The seasonal variation of nonmethane hydrocarbons in the free troposphere over the North Atlantic Ocean: Possible evidence for extensive reaction of hydrocarbons with the nitrate radical, J. Geophys. Res., 98, 2865-2885, 1993.

Pochanart, P., Hirokawa, J., Kajii, Y., and Akimoto, H.: Influence 
of regional-scale anthropogenic activity in northeast Asia on seasonal variations of surface ozone and carbon monoxide observed at Oki, Japan, J. Geophy. Res., 104(D3), 3621-3631, 1999.

Pochanart, P., Akimoto, H., Kinjo, Y., and Tanimoto, H.: Surface ozone at four remote island sites and the preliminary assessment of the exceedances of its critical level in Japan, Atmos. Environ., 36, 4235-4250, 2002.

Pochanart, P., Akimoto, H., Kajii, Y., and Sukasem, P.: Regional background ozone and carbon monoxide variations in remote Siberia/East Asia, J. Geophys. Res., 108(D1), 4028, doi:10.1029/2001JD001412, 2003.

Pudasainee, D., Sapkota, B., Shrestha, M. L., Kaga, A., Kondo, A., and Inoue, Y.: Ground level ozone concentrations and its association with $\mathrm{NO}_{\mathrm{x}}$ and meteorological parameters in Kathmandu valley, Nepal. Atmos. Environ., 40(40), 8081-8087, 2006.

Sudo, L., Takahashi, M., Kurokawa, J., and Akimoto, H.: CHASER: a global chemical model of the troposphere -1 . Model description, J. Geophys. Res.-Atmos., 107(D17), 4339, doi:10.1029/2001JD001113, 2002.

Staehelin, J., Thudium, J., Buehler, R., Volz-Thomas, A., and Graber, W.: Trends in surface ozone concentrations at Arosa (Switzerland), Atmos. Environ., 28, 75-87, 1994.

Tanimoto, H., Sawa, Y., Matsueda, H., Uno, I., Ohara, T., Yamaji, K., Kurokawa, J., and Yonemura, S.: Significant latitudinal gradient in the surface ozone spring maximum over East Asia, Geophys. Res. Lett., 32, L21805, doi:10.1029/2005GL023514, 2005.

Tu, J., Xia, Z. G., Wang, H., and Li, W.: Temporal variations in surface ozone and its precursors and meteorological effects at an urban site in China, Atmos. Res., 85(3-4), 310-337, 2007.

Uno, I., He, Y., Ohara, T., Yamaji, K., Kurokawa, J.-I., Katayama, M., Wang, Z., Noguchi, K., Hayashida, S., Richter, A., and Burrows, J. P.: Systematic analysis of interannual and seasonal variations of model-simulated tropospheric $\mathrm{NO}_{2}$ in Asia and comparison with GOME-satellite data, Atmos. Chem. Phys., 7, 16711681, 2007, http://www.atmos-chem-phys.net/7/1671/2007/.

Wang, H. X., Zhou, L. J., and Tang, X. Y.: Ozone concentrations in rural regions of the Yangtze Delta in China, J. Atmos. Chem., 54(3), 255-265, 2006.

Wang, T. J., Lam, K. S., Xie, M., Wang, X. M., Carmichael, G., and Li, Y. S.: Integrated studies of a photochemical smog episode in Hong Kong and regional transport in the Pearl River Delta of China, Tellus B, 58(1), 31-40, 2006.
Wang, T., Cheung, V. T., Lam, K. S., Kok, G. L., and Harris, J.: The characteristics of ozone and related compounds in the boundary layer of the South China coast: temporal and vertical variations during autumn season, Atmos. Environ., 35(15), 27352746, 2001.

Wang, Z. F., Li, J., Wang, X. Q., Pochanart, P., and Akimoto, H.: Modeling of regional high ozone episode observed at two mountain sites (Mt. Tai and Huang) in East China, J. Atmos. Chem., 55, 253-272, doi:10.1007/s10874-006-9038-6, 2006.

Wild, O. and H. Akimoto: Intercontinental transport of ozone and its precursors in a three-dimensional global CTM, J. Geophys. Res., 106, 27729-27744, 2001.

Xu, J. L., Zhu, Y. X., and Li, J. L.: Seasonal cycles of surface ozone and $\mathrm{NO}_{\mathrm{x}}$ in Shanghai, J. Appl. Meteorol., 36(10), 1424-1429, 1997.

Yamaji, K., Ohara, T., Uno, I., Tanimoto, H., Kurokawa, J., and Akimoto, H.: Analysis of the seasonal variation of ozone in the boundary layer in East Asia using the Community Multiscale Air Quality model: What controls surface ozone levels over Japan?, Atmos. Environ., 40(10), 1856-1868, 2006.

Zbinden, R. M., Cammas, J.-P., Thouret, V., Nédélec, P., Karcher, F., and Simon, P.: Mid-latitude tropospheric ozone columns from the MOZAIC program: climatology and interannual variability, Atmos. Chem. Phys., 6, 1053-1073, 2006, http://www.atmos-chem-phys.net/6/1053/2006/.

Zhang, M. G., Uno, I., Sugata, S., Wang, Z. F., Byun, D., and Akimoto, H.: Numerical study of boundary layer ozone transport and photochemical production in east Asia in the wintertime, Geophys. Res. Lett., 29(11), 1545, doi:10.1029/2001GL014368, 2002.

Zhang, M. G., Uno, I., Carmichael, G. R., Akimoto, H., Wang, Z. F., Tang, Y. H., Woo, J. H., Streets, D. G., Sachse, G. W., Avery, M. A., Weber, R. J., and Talbot, R. W.: Large-scale structure of trace gas and aerosol distributions over the western $\mathrm{Pa}$ cific Ocean during the Transport and Chemical Evolution Over the Pacific (TRACE-P) experiment, J. Geophys. Res., 108(D21), 8820, doi:10.1029/2002JD002946, 2003.

Zhang, M. G., Xu, Y. F., Uno, I., and Akimoto, H.: A numerical study of tropospheric ozone in the springtime in East Asia, Adv. Atmos. Sci., 21(2), 163-170, 2004.

Zhu, B., Akimoto, H., Wang, Z., Sudo, K., Tang, J., and Uno, I.: Why does surface ozone peak in summertime at Waliguan?, Geophys. Res. Lett., 31, L17104, doi:10.1029/2004GL020609, 2004. 